\title{
Sedimentology of Marl and Marly Limestone Sequence of Upper Cretaceous Kawagarh Formation from Northern Kalachitta Range, Attock Hazara Fold and Thrust Belt, Pakistan
}

\author{
Saif Ur Rehman ${ }^{*}$, Khalid Mehmood ${ }^{1}$, Muhammad Fahad Ullah', Naveed Ahsan', \\ Faisal Rehman', Tariq Mahmood ${ }^{3}$, Mahboob Ahmed ${ }^{1}$ \\ ${ }^{1}$ Department of Earth Sciences, University of Sargodha, Sargodha, Pakistan \\ ${ }^{2}$ Institute of Geology, University of the Punjab, Lahore, Pakistan \\ ${ }^{3}$ Oil and Gas Development Corporation Limited, Islamabad, Pakistan \\ Email: *saif.rehman@uos.edu.pk
}

How to cite this paper: Rehman, S.U., Mehmood, K., Ullah, M.F., Ahsan, N., Rehman, F., Mahmood, T. and Ahmed, M. (2019) Sedimentology of Marl and Marly Limestone Sequence of Upper Cretaceous Kawagarh Formation from Northern Kalachitta Range, Attock Hazara Fold and Thrust Belt, Pakistan. Open Journal of Geology, 9, 1-14.

https://doi.org/10.4236/ojg.2019.91001

Received: November 8, 2018

Accepted: January 8, 2019

Published: January 11, 2019

Copyright $\odot 2019$ by author(s) and Scientific Research Publishing Inc. This work is licensed under the Creative Commons Attribution International License (CC BY 4.0).

http://creativecommons.org/licenses/by/4.0/

\section{(c) (i) Open Access}

\begin{abstract}
Upper Cretaceous Kawagarh Formation is well exposed in the Attock Hazara Fold and Thrust Belt (AHFTB) and shows significant lateral and vertical variations in lithology. The present work deals with the sedimentological studies of marl and marly limestone sequence of Kawagarh Formation exposed at the Bagh Neelab, Ghariala north and Sojhanda villages in Northern Kalachitta Range. Detailed petrographic studies of marly limestone and hard marl substrate show that planktons and oysters are the main skeletal constituents of studied samples and clay and detrital quartz mainly composed the non skeletal fraction. X-Ray diffraction analyses of selected marl samples confirm the petrographic data. On the basis of skeletal and non skeletal content, two microfacies-marl microfacies and Planktonic microfacies are constructed. The faunal content, their paleoecology and detrital content of microfacies suggest that marl and marly limestone sequence of Kawagarh Formation was deposited over the mid and outer ramp settings.
\end{abstract}

\section{Keywords}

Attock Hazara Fold \& Thrust Belt, Fauna, Kalachitta Range, Microfacies, Ramp

\section{Introduction}

Marls represent sole variety of mixed siliciclastic-carbonate rock that contains 
variable amount of clays along with carbonate minerals. They frequently occur with limestone of diverse depositional environments. Marls are commonly interpreted as deposition of distal and deep marine settings including outer shelf and pelagic environments [1] [2] [3] [4] [5]. However, it has been developed under relatively shallow marine conditions like mid shelf environments [6] [7].

Upper Cretaceous Kawagarh Formation is well exposed throughout the Attock Hazara Fold and Thrust Belt (AHFTB) including the Hazara Basin and Kalachitta Range (Figure 1). It is very diverse in lithology and shows considerable lateral and vertical variations in different parts the AHFTB [6] [8] [9]. In Hazara Basin, the eastern part of AHFTB, Kawagarh Formation is represented by a sequence of limestone with subordinate dolomite and marl [6] [7] [10] [11] [12]. Marls are absent in the northern part of Hazara Basin [7] [11]. In Kalachitta Range, the western extremity of AHFTB, it is composed of limestone and marl with minor marly limestone and dolomite [6]. Limestone and marl constitute as major lithofacies in the southern part of Kalachitta Range whereas the northern part of Kalachitta Range is exclusively represented by the sequence of marl and marly limestone [6] [8] [13]. The southern sections of Kawagarh Formation are well studied in terms of Sedimentology and paleontology but no significant sedimentological record is available on the marl and marly limestone sequence of northern sections.

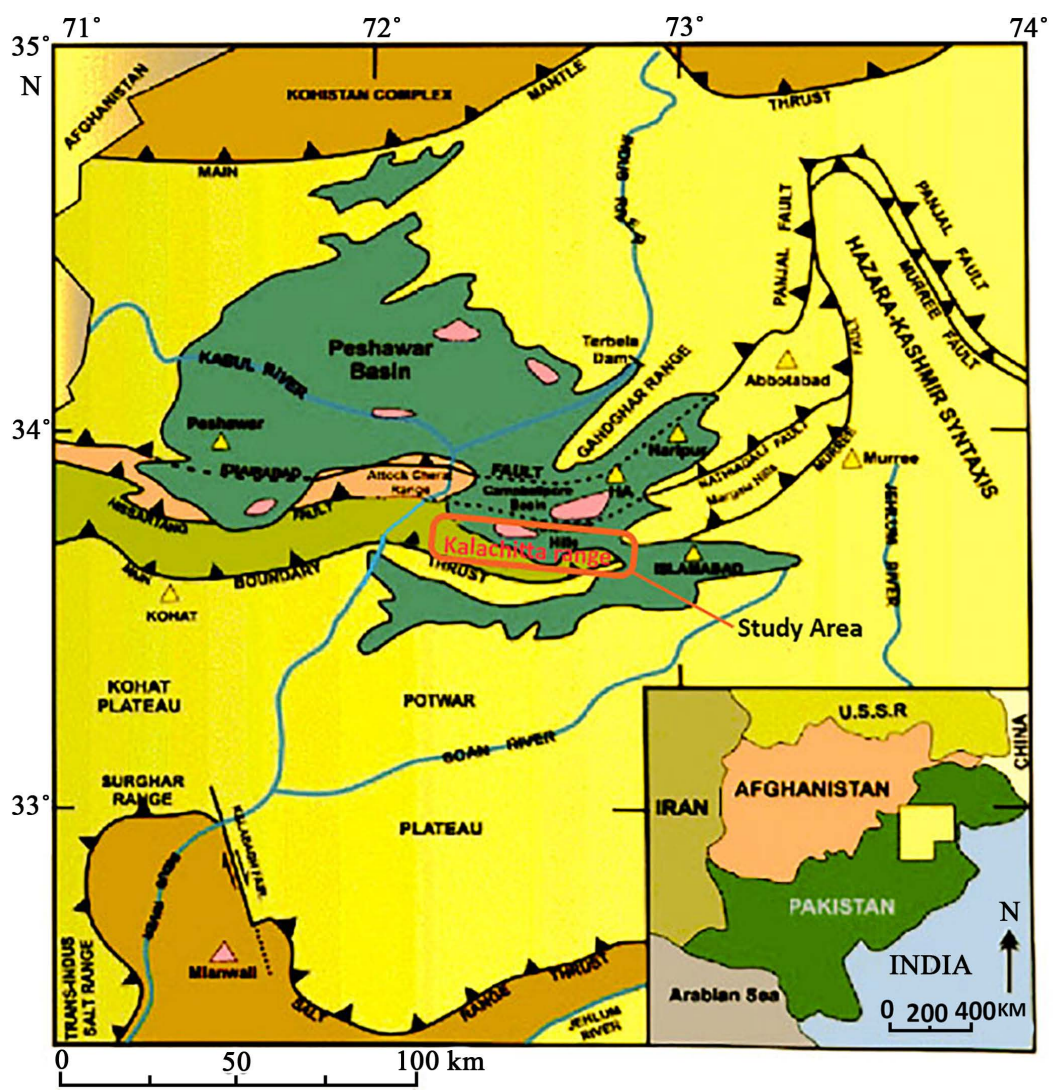

Figure 1. Generalized location and tectonic map of Northern Pakistan modified after [14] [15]. Red inset showing the location of study area. 
The present work mainly focuses on the sedimentological attributes including detrital and carbonate contents, faunal assemblage and sedimentary structures of marl and marly limestone sequence of Kawagarh Formation exposed in the northern Kalachitta Range to depict their depositional settings.

\section{Regional Geology}

Kalachitta Range, the part of AHFTB (Figure 1) is resulted by deformation and uplift of northern margin of India after the Late Eocene Indo-Asia continent-continent collision [16] [17] [18] [19] [20]. It constitutes the southernmost part of Lesser Himalaya in the west of Hazara Basin [17] [21]. Kalachitta Range is bounded by Main Boundary Thrust (MBT) and Nathia Gali Thrust (NGT) or Hissartang Fault (HF) in south and north respectively [15] [22]. It is truncated by Margalla Range in east and separated from Nizampur Basin in west by Indus River [15] [23]. Kalachitta Range is characterized by series of southward verging thrusts and wedge shaped structural geometry [23]. Kalachitta Range exhibits sequence of sedimentary rocks ranging in age from Triassic to Miocene-Pliocene (Figure 2) [8] [13] [24] [25]. MBT emplaced the sedimentary sequence of Kalachitta Range over the rocks of Northern Potwar Deformed Zone in south [23] [26]. This sedimentary sequence of Kalachitta Range is covered by the sediments of Cambellpur Basin in the north of Kalachitta Range [23].

\begin{tabular}{|c|c|c|c|c|c|}
\hline \multicolumn{3}{|c|}{ Age } & \multirow{2}{*}{$\begin{array}{l}\text { Formation } \\
\text { Murree Formation }\end{array}$} & \multicolumn{2}{|r|}{ Lithology } \\
\hline \multirow{10}{*}{$\begin{array}{l}\mathrm{C} \\
\mathrm{e} \\
\mathrm{n} \\
\mathrm{o} \\
\mathrm{z} \\
\mathrm{o}\end{array}$} & $\begin{array}{l}\text { 으 } \\
\text { a } \\
\text { t } \\
e \\
r \\
r \\
a \\
r \\
r \\
y\end{array}$ & $\begin{array}{l}\text { Miocene- } \\
\text { Pliocene }\end{array}$ & & & $\begin{array}{l}\text { Sandstone \& clays/shale } \\
\text { with minor siltstone \& } \\
\text { claystone }\end{array}$ \\
\hline & \multirow{9}{*}{$\begin{array}{l}\mathrm{T} \\
\mathrm{e} \\
\mathrm{r} \\
\mathrm{t} \\
\mathrm{i} \\
\mathrm{a} \\
\mathrm{r} \\
\mathrm{y}\end{array}$} & \multirow{5}{*}{ Eocene } & Unconformity & 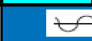 & תת \\
\hline & & & Kohat Formation & & Limestone \& shale \\
\hline & & & Kuldana Formation & & Shales,limestone \& sandstone \\
\hline & & & Chorgali Formation & & Limestone \& shale \\
\hline & & & Margala Hill Limestone & +1 & Nodular limestone \& marl \\
\hline & & \multirow{3}{*}{ Paleocene } & Patala Formation & & Shales,limestone \& sandstone \\
\hline & & & Lockhart Limestone & & Nodular limestone \\
\hline & & & Hangu Formation & & Ferruginous Sandstone \\
\hline & & \multirow{4}{*}{ Cretaceous } & Unconformity & & صथि \\
\hline \multirow{3}{*}{\multicolumn{2}{|c|}{ M }} & & Kawagrah Formation & & Marl , marly limestone, limestone \\
\hline & & & Lumshiwal Formation & & Sandstone \& shale \\
\hline & & & Chichali Formation & $-=$ & Shale, minor sandstone \\
\hline \multirow{2}{*}{\multicolumn{2}{|c|}{$\begin{array}{l}\mathrm{e} \\
\mathrm{s}\end{array}$}} & \multirow{5}{*}{ Jurassic } & Disconformity & \multicolumn{2}{|c|}{ טתกת } \\
\hline & & & Samana Suk Formation & & Oolitic limestone \\
\hline \multicolumn{2}{|c|}{0} & & Shinawari Formation & & Limestone, marl/shale \\
\hline \multirow{2}{*}{\multicolumn{2}{|c|}{ Z }} & & Datta Formation & $=$ & Quartzose sandstone, shale \\
\hline & & & Unconformity & \multicolumn{2}{|c|}{ טת } \\
\hline \multirow{3}{*}{\multicolumn{2}{|c|}{$\begin{array}{l}\mathrm{O} \\
\mathrm{i} \\
\mathrm{C}\end{array}$}} & \multirow{3}{*}{ Triassic } & Kingriali Formation & & Dolomite, Dolomitic limestone \\
\hline & & & Chak Jabbi Limestone & & Limestone \\
\hline & & & Mianwali Formation & $\frac{1}{1}$ & Limestone, sandstone \& shale \\
\hline
\end{tabular}

Figure 2. Stratigraphic column of Kalachitta Range, Pakistan [8] [13]. 


\section{Materials and Methods}

After the thorough field excursion of northern and northwestern Kalachitta Range, three stratigraphically complete sections of Kawagarh Formation exposed at Bagh Neelab, Ghariala north and Sojhanda villages, Attock district were selected for the Sedimentological studies. All sections were exposed excellently with preserved bottoms and tops and least deformation. All sections were measured by using Jaccob Staff apparatus and measuring tape [27]. The outcrop data of studied sections including lithology, color, sedimentary structures, grain size, fauna, bedding, contacts etc. were recorded on the Field data sheets. A total of 17, 19 and 21 samples were collected from Sojhanda, Ghariala and Bagh Neelab respectively. Collection of samples had been done at suitable intervals as per variations in lithology and thickness of different beds from all three sections. Each bed of marly limestone was sampled whereas only one sample was collected from the each marl horizon. Samples of limestone and marl were transported to laboratory for petrographic and mineralogical studies.

The limestone samples and selected hard chips of marls were thin sectioned. Thin sections were stained following the staining technique of given by Dickson, J. (1965) [28]. Thin sections were analyzed by using Polarizing microscope to determine the skeletal and non skeletal grains, matrix and depositional fabric of studied samples. The detrital content and mineral compositions of marls were also determined by the X-Ray diffraction analyses. The microscopic and X-Ray diffraction data of studied samples were used to construct the microfacies to deduce the depositional environments of studied sections. Deposition environments of microfacies were used to establish the depositional model of marl and marly limestone sequence of Kawagarh Formation exposed in the northern part of Kalachitta Range.

\section{Results and Discussions}

\subsection{Outcrop Geology}

In northern Kalachitta Range, Kawagarh Formation is mainly comprised of marl with subordinate marly limestone (Figure 3(a) \& Figure 3(b)). Marl is generally light grey to medium grey and occasionally greenish grey on fresh surface and shows different weathering colors like yellowish brown and rusty brown (Figure 3(b) \& Figure 3(c)). It contains silty and sandy concretions at places and also shows broken shell fragments at places. Marls are generally compacted and cleaved and also show some hard substrate at places. Marly limestone is generally light grey to medium grey and thin bedded to medium bedded with occasional thick beds. It is generally unfossiliferous and contains some burrows which are identified as Thalssinoids of Cruzania class (Figure 3(d)). The lower contact of Kawagarh Formation is slightly gradational which is marked by Lumshiwal Formation (Figure 3(e)) while the upper contact followed by the lateritic clays of KT Boundary (Figure 3(f)). 

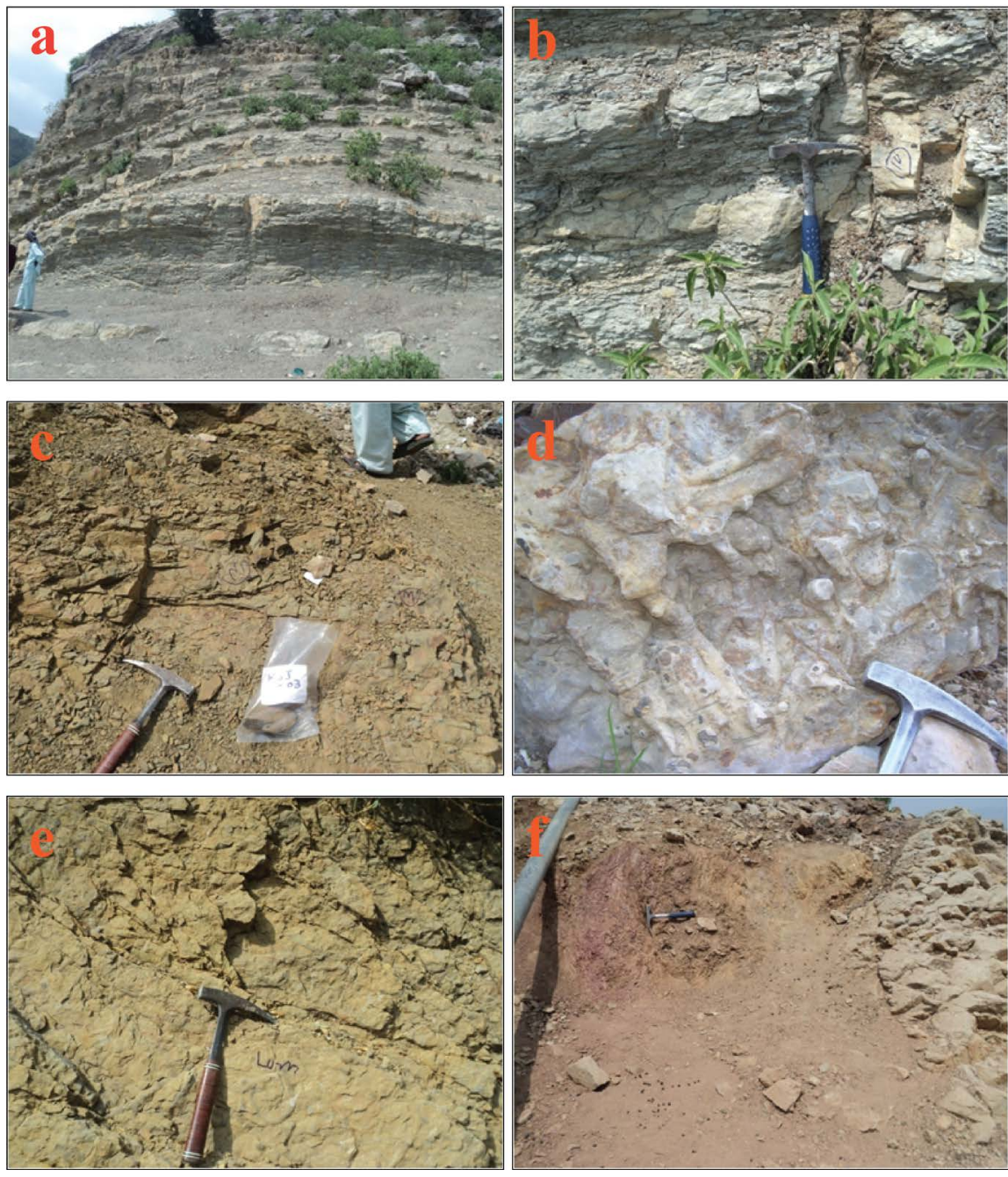

Figure 3. (a) Interbeded light grey to medium grey marl and marly limestone at Bagh Neelab Section; (b) Light grey marl with interbedded grey marly limestone band, Ghariala north Section; (c) Greenish grey marls with yellowish brown weathered surface at Sojhanda Section; (d) Thalssinoids burrows in marly limestone at Ghariala north Section; (e) Ferruginous sandstone at the top of Lumshiwal Formation at Sojhanda Section; (f) Laterite at the top of Kawagarh Formation at Bagh Neelab Section.

The skeletal content mainly includes the Planktonic foraminifera and benthic fragments of oysters, trigonia and brachiopods. Non skeletal grains mainly include detrital quartz and dolomite. Some sedimentary structures including horizontal and inclined burrows, abraded shells and graded bedding were also recorded in some samples. The petrographic data including type and abundance of skeletal grains and non skeletal grains, matrix and sedimentary structures were recorded and used to construct the microfacies.

\subsection{Microfacies}

Microfacies analyses are frequently used to deduce the depositional settings of ancient carbonate and mixed siliciclastic-carbonate rocks [3] [27]. In present study classification of [29] has been used with slight modifications suggested by 
[27] to construct the microfacies. The names of microfacies were assigned on basis of dominant biota type.

\subsection{Marl Microfacies}

Thin section studies of hard chips of marl samples show that marls contain minute content of biota. The skeletal content generally ranges from $4 \%$ to $6 \%$. The preservation of biota is generally very poor. The skeletal content is mainly comprised of planktons and bioclasts of oysters with trace occurrence of brachiopod and trigonia (Figure 4(a) \& Figure 4(b)). Planktons generally include the globotruncana with trace occurrence of heterohelix at places. The skeletal grains are widely distributed over the fine grained clayey and calcitic matrix. Planktons are generally $0.1 \mathrm{~mm}$ to $0.26 \mathrm{~mm}$ in size (Figure $4(\mathrm{a})$ ). The plankton chambers are frequently replaced with sparite. The broken tests of planktons also occur at places. Oysters are generally broken and show the effect of abrasion marked by the sharp and modified margins (Figure $4(\mathrm{~b})$ ). The size of oysters generally ranges from $0.3 \mathrm{~mm}$ to $0.42 \mathrm{~mm}$. Inclined burrows rarely occur in this
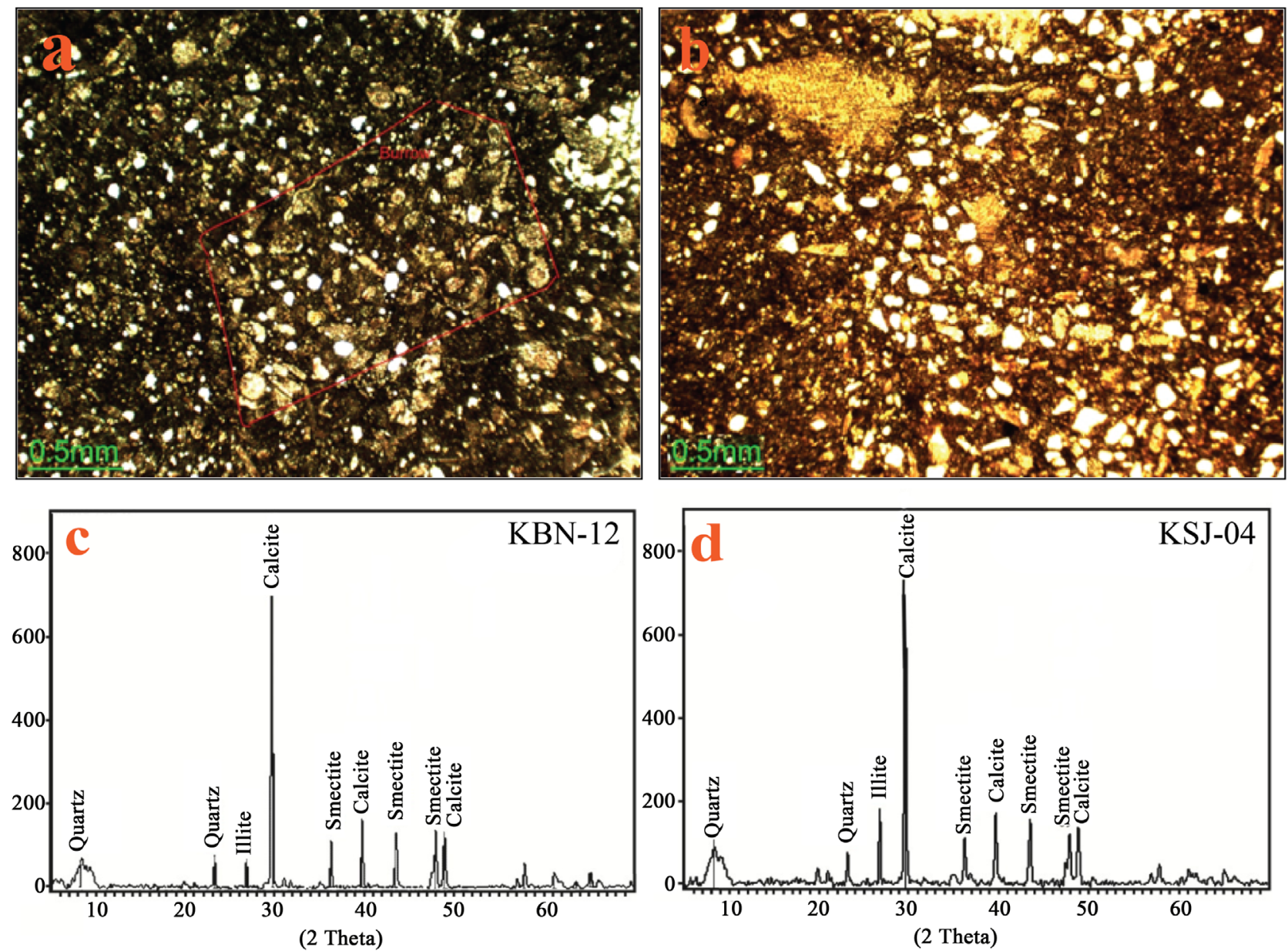

Figure 4. (a) Planktons, detrital quartz and oysters with abraded margins in Marl microfacies, Sojhanda Section; (b) Oysters with abraded and consumed margins and detrital quartz in Marl microfacies, Bagh Neelab Section; (c) XRD curve of marl sample (KBN-12), Bagh Neelab Section; (d) XRD curve of marl sample (KSJ-04), Sojhanda Section. 
microfacies. Clay and quartz represent the major detrital constituents of marl microfacies. Clays composed the fine grained matrix along with substantial amounts of calcite. Quartz grains are generally sub angular to sub rounded and very fine to silt sized (Figure 4(a) \& Figure 4(b)). The quartz content ranges from $10 \%$ to $20 \%$.

The XRD analyses of selected bulk samples of marl microfacies show that the marls are mainly composed of clay minerals including smectite and illite with subordinate calcite and quartz in sample (KBN-12) and (KSJ-04) samples (Figure $4(\mathrm{c})$ \& Figure $4(\mathrm{~d})$ ). The total clay content is ranges from $50 \%$ to $65 \%$ and calcite content varies from $20 \%$ to $28 \%$. The detrital quartz content is evaluated from $10 \%$ to $18 \%$.

\subsection{Planktonic Wackestone and Packstone Microfacies}

Marly limestone generally represents Planktonic microfacies which are characterized by the dominancy of Planktonic foraminifera (Figure 5(a) \& Figure 5(b)). Palnktonic foraminifera are comprised of Globotruncandae with rare occurrence of Globigerinoidae and Heterohelix (Figure 5(b) \& Figure 5(c)). Planktonic content generally ranges from $25 \%$ to $32 \%$ with an average of $28 \%$ in wackestone microfacies and it varies from $52 \%$ to $60 \%$ in packstone microfacies with a mean of $55 \%$ (Figure $5(\mathrm{~d})$ ). The size of planktons generally varies from $0.25 \mathrm{~mm}$ to 0.6 $\mathrm{mm}$.
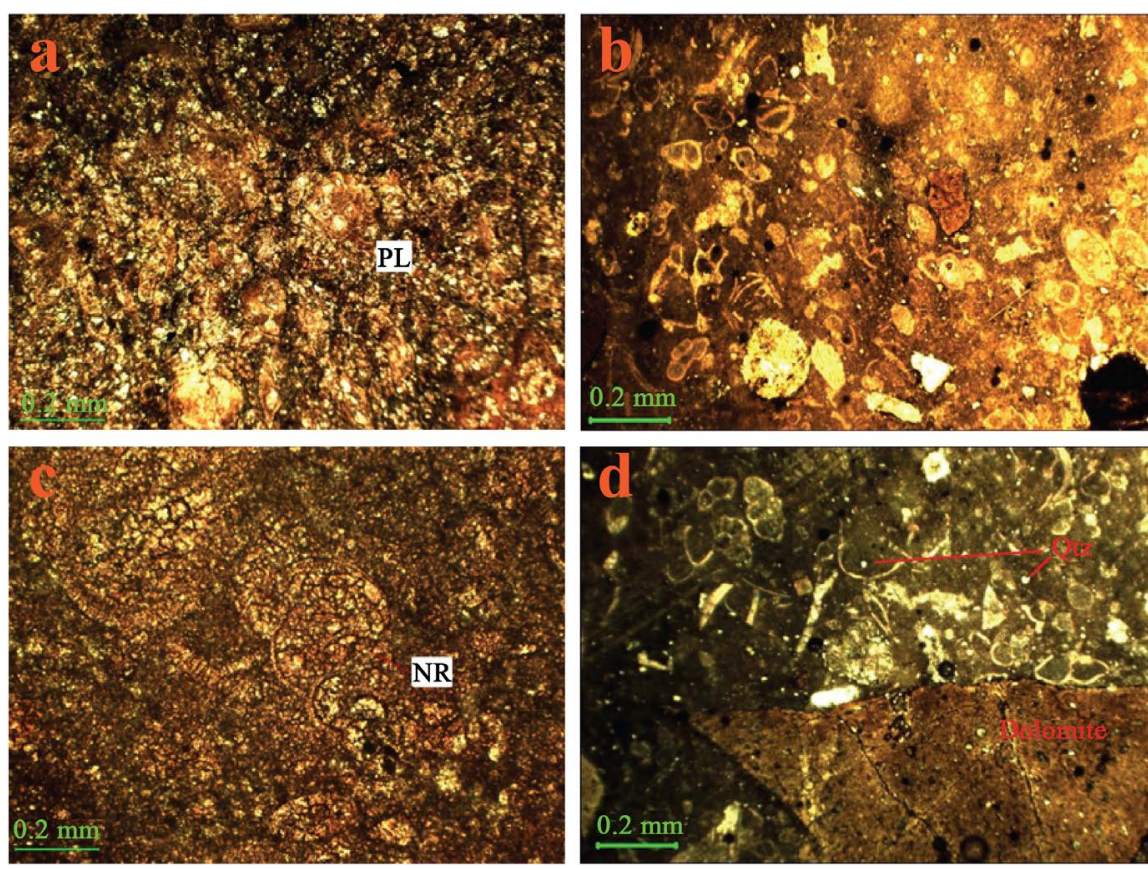

Figure 5. (a) Neomorphosed planktons in Planktonic Packstone microfacies, Bagh Neelab Section; (b) Planktons with minor quartz in Planktonic wackestone microfacies, Ghariala North; (c) Sparry chambers of Heterohelix in Planktonic wackestone microfacies, Bagh Neelab Section; (d) Large dolomite crystal and very fine quartz in Planktonic wackestone microfacies, Ghariala North Section. 
Planktons are moderately to poorly preserved and their chambers are generally neomorphosed by the sparite whereas the peripheries are replaced by the microspar (Figure $5(\mathrm{c})$ ). Chambers are also replaced by the dolomite at places. Planktons are broken at places and intact to broken ratio is about 3:1.

Detrital quartz and dolomite are major non skeletal grains of this microfacies (Figure 5(d)). Quartz grains are generally sub rounded and silt sized. The quartz content generally ranges from $3 \%$ to $5 \%$. Dolomite generally occurs in form of small rhombic crystals and its content ranges from $1 \%$ to $2 \%$. Inclined burrows are the only sedimentary structures of this microfacies and occur at places. The groundmass is generally fine grained and is dominantly composed of clay and calcite.

\section{Depositional Environments}

Unlike the clastic sedimentary rocks, the paleoecology of skeletal grains along with microfacies analyses is the only reliable criteria to decipher the depositional environments in carbonate rocks due to the lack of sedimentary structures [3] [7] [27] [30] [31] [32]. In present study, the paleoecology of skeletal grains has been used to deduce the depositional environments of studied sequence of marl and marly limestone. Petrographic studies show that planktons and oysters are the main skeletal constituents of both microfacies.

Planktonic foraminifera are significantly used to constraint the biochronology and paleo environments in ancient carbonate rocks [33] [34]. Planktons occur in diverse depositional environments ranging from shallow shelves to deep water systems like ocean basin in varying amounts [1] [3] [7] [27] [32] [35] [36]. The frequency of planktons is greatly affected by depth as very low over the shallow shelve up to $50 \mathrm{~m}$ depth and common to abundant at the deeper parts of shelves more than 50 m depth [37] [38] [39] [40]. Planktons generally coexist in minor amounts with high frequency of benthons over the shallow shelves [34] [41].

Oysters, the sub group of bivalves abundantly constitute the Mesozoic sedimentary rocks of diverse environments ranging from near shore settings to deeper shelves [42] [43] [44]. They generally occur in large amounts over shallow shelves and near shore environments [42] [43] [44] reported them from limestone and sandstone of shallow shelf environments. Furthermore, [44] marked a gradual decrease in frequency of oysters with increase of depth and placed them over the shallow shelve and shore face settings. The above mentioned paleoecological constraints of planktonic foraminifera and oysters clearly indicate that the studied microfacies of Kawagarh Formation exposed in the northern Kalachitta Range were deposited over open marine conditions under the moderately to deep water depths.

\section{Depositional Model}

Carbonate deposition generally occurs in five distinct settings including rimmed shelves, non rimmed shelve, ramps, epeiric platforms and isolated platforms, 
characterized by the various depositional features and facies [27] [45] [46] [47] [48]. The absence of reefal facies, carbonate sand shoals, slump structures and pelagic sediments infer ramp settings for the deposition of Upper Cretaceous Kawagarh Formation (Figure 6). Similar ramp settings have inferred for Kawagarh Formation exposed in the Hazara Basin and Kalachitta Range [6] [7] [32] [49].

Ramp can be further divided into three sub settings including inner ramp, mid ramp and outer ramp on the basis of Fair Weather Wave Base (FWWB) and Storm Wave Base (SWB). The absence of oolitic facies, high frequency of benthic fauna and grainstone microfacies in the studied samples indicate that the studied microfacies were deposited below the FWWB. The occurrence of planktons along with broken pieces of oysters and low to common frequency of Planktonic foraminifera in marl microfacies suggest mid ramp settings, a transition between inner and outer ramp settings (Figure 6). [50] [51] characterized the mid ramp facies by the low frequency of planktons and bioclasts, winnowed shells, hummocky cross stratification and fine grained detrital sediments transported by the storm action. The substantial amounts of very fine grained to silt sized detrital quartz $(15 \%-18 \%)$ also indicate a slightly land distal mid ramp settings for the deposition of marl microfacies. Fauna is generally poorly sorted within marl microfacies which are diagnostic feature of storm deposits. Furthermore, the abraded shells of oysters strongly indicate the transportation of oysters form the shallow settings caused by the storm action.

The marly limestones are represented by the Planktonic wackestone and packstone microfacies which are interpreted as outer ramp facies deposited below the SWB (Figure 6). Outer ramp facies are generally characterized by the high frequency of planktons, absence of benthons, lack of detrital material with abundant wackestone and packstone assemblage [3] [27] [36] [50]. The common to abundant occurrence of Planktonic foraminifera in Planktonic wackestone and packstone microfacies and their paleoecology suggested land distal low energy conditions like outer ramp settings for the deposition of these microfacies as discussed above [1] [3] [7] [27] [32] [35] [36]. The low content of detrital quartz also suggests distal deep water settings for Planktonic microfacies. Furthermore,

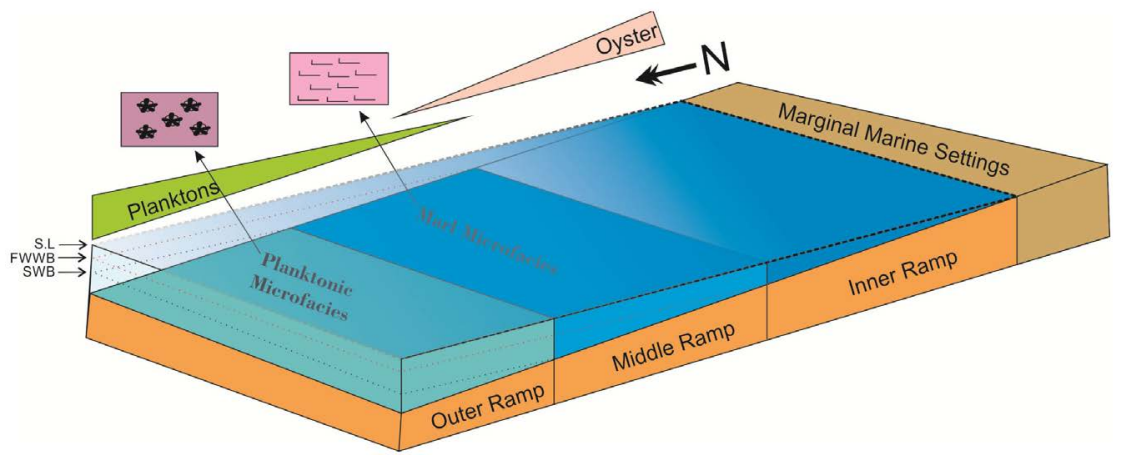

Figure 6. Paleoecological and depositional model for upper cretaceous Kawagarh formation. 
the absence of slope structure, pelagic sediments and bedded cherts also confer a deep ramp conditions like outer ramp for the deposition of these microfacies.

\section{Discussion}

In vertical profiles of all three studied sections of Late Turonian to Early Maastrichtian Kawagarh Formation, the bases of all sections are marked by the marl microfacies (Figure 7) directly residing over the ferruginous and slightly calcareous sandstone of Lumshiwal Formation with sharp but slightly gradational contact (Figure 3(e)). Further, the marl microfacies are followed by Planktonic wackestone and packstone microfacies in all studied sections. This overlapping pattern of microfacies demarcates transgression at the bases all studied sections (Figure 7). The gradual increase in the frequency of planktons and decrease in detrital content from underlying marl microfacies to Planktonic microfacies also indicates gradual increase in the water depth [1] [5] [7] [36] [39]. This transgression corresponds to Late Turonian global sea level rise as marked on the global sea level curve of [52]. The transgressive cycles are further followed by the regressive cycles in all studied sections. Maximum six sea level changes (including three transgressions and three regressions) have been recorded at easternmost section of Kawagarh Formation exposed at Bagh Neelab (Figure 7) while other two sections including Ghariala north and Sojhanda sections are characterized by four sea level changes. The tops of all studied sections are characterized by regressive cycles marked by the deposition of marl microfacies which are further followed by the lateritic clays of KT Boundary which marks the uplift and/or exposure of Kawagarh Formation.
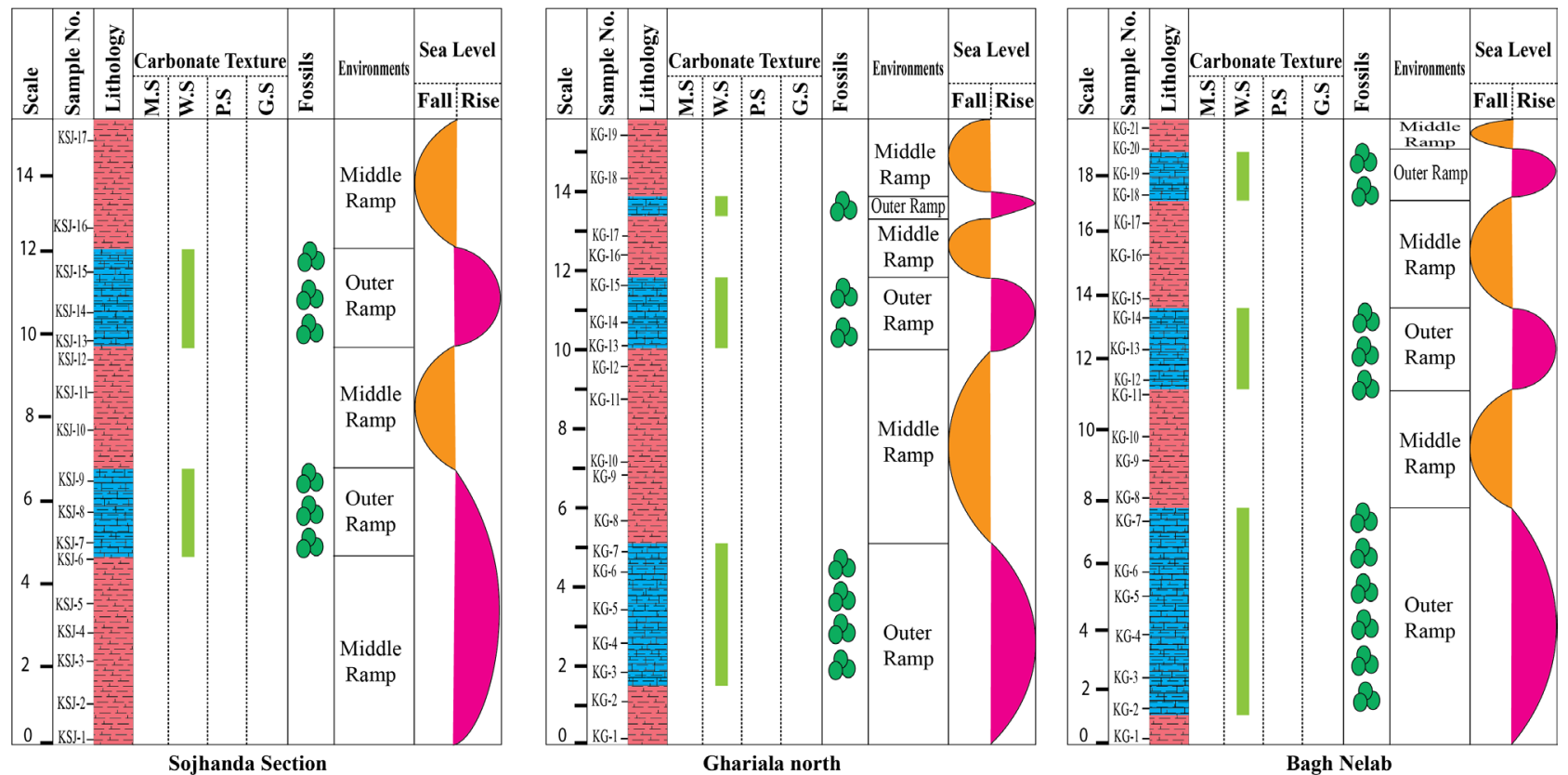

Figure 7. Lithological and microfacies charts of Bagh Nelab, Ghariala north and Sojhanda Section. 


\section{Conclusion}

The outcrop data, microfacies analyses and the absence of slope features, reefal facies and ocean basin sediments clearly infer the ramp settings for the deposition of Upper Cretaceous Kawagarh Formation exposed in the northern Kalachitta Range. The marl microfacies were deposited under mid ramp settings while the marly limestone was deposited over the outer ramp settings. The inner ramp deposition is not recorded in the northern Kalachitta Range which indicates that the study area was located significantly distant from the land during the deposition of Kawagarh Formation.

\section{Conflicts of Interest}

The authors declare no conflicts of interest regarding the publication of this paper.

\section{References}

[1] Butt, A.A. (1986) Cretaceous Biostratigraphic Synthesis of Pakistan. Acta Mineralogica Pakistanic, 2, 60-64.

[2] Bellanca, A., Di Stefano, P. and Neri, R. (1995) Sedimentology and Isotope Geochemistry of Carnian Deep-Water Marl/Limestone Deposits from the Sicani Mountains, Sicily: Environmental Implications and Evidence for a Planktonic Source of Lime Mud. Palaeogeography, Palaeoclimatology, Palaeoecology, 114, 111-129. https://doi.org/10.1016/0031-0182(95)00077-Y

[3] Tucker, M.E. (2009) Sedimentary Petrology: An Introduction to the Origin of Sedimentary Rocks. John Wiley \& Sons, New York.

[4] Pomar, L., Molina, J.M., Ruiz-Ortiz, P.A. and Vera, J.A. (2017) Storms in the Deep: Tempestite- and Beach-Like Deposits in Pelagic Sequences (Middle-Upper Jurassic, Subbetic, South of Spain). EGU General Assembly Conference Abstracts, 19, 3929.

[5] Rehman, S.U., Riaz, M.A., Ahmed, M., Ullah, M.F., Kashif, M. and Rehman, F. (2017) Sedimentology of Pir Koh Formation Exposed at Dholi and Rakhi Gaj, Central Sulaiman Range, Pakistan. Journal of Biodiversity and Environmental Sciences, 11, 224-234.

[6] Rehman, S.U. (2017) Sedimentology of Turonian-Maastrichtian Kawagarh Formation, Attock Hazara Fold and Thrust Belt, Northwestern Lesser Himalayas, Pakistan. Unpublished Ph.D Thesis, University of Sargodha, Pakistan.

[7] Rehman, S.U., Mehmood, K., Ahsan, N. and Shah, M.M. (2016) Microfacies and Depositional Environments of Upper Cretaceous Kawagarh Formation from Chinali and Thoba Section, Northeastern Hazara Basin Lesser Himalayas, Pakistan. Journal of Himalayan Earth Sciences, 49, 1-16.

[8] Shah, S.M.I (2009) Stratigraphy of Pakistan: Geol. Surv. Pakistan, Quetta No. 22.

[9] Qureshi, M.K.A., Ghazi, S., Butt, A.A., Ahmad, N., Dasti, N. and Masood, K.R. (2004) Biostratigraphy and Sedimentology of the Upper Cretaceous Kawagarh Formation, Kala Chitta Range, Lesser Himalayas, Pakistan. Geological Bulletin of the Punjab University, 39, 37-46.

[10] Rehman, S.U. (2009) Microfacies and Depositional Environments of Kawagarh Formation Exposed at Chinali and Khariala, Northwest Lesser Himalayas, Pakistan. Unpublished M. Phil Thesis, Punjab University, Lahore. 
[11] Ahsan, N. and Chaudhry, M.N. (2008) Geology of Hettangian to Middle Eocene Rocks of Hazara and Kashmir Basins, Northwest Lesser Himalayas, Pakistan. Geological Bulletin of Punjab University, 43, 131-152.

[12] Latif, M.A. (1970) Explanatory Notes on the Geology of Southern Hazara, to Accompany the Revised Geological Map. Jahrbuch der Geologischen Bundesanstalt, Sonderband, 15, 5-20.

[13] Shah, S.M.I (1977) Stratigraphy of Pakistan: Geol. Surv. Pakistan, Quetta, No. 12.

[14] Calkins, J.A., Offield, T.W., Abdullah, T.S.K.M. and Ali, S.T. (1975) Geology of the Southern Himalaya in Hazara, Pakistan and Adjacent Areas. USGS Prof. Paper 716-c.

[15] Yeats, R.S. and Hussain, A. (1987) Timing of Structural Events in the Himalayan Foothills of Northwestern Pakistan. Geological Society of America Bulletin, 99, 161-176. https://doi.org/10.1130/0016-7606(1987)99<161:TOSEIT>2.0.CO;2

[16] Powell, C.M. (1979) A Speculative Tectonic History of Pakistan and Surroundings: Some Constraints from the Indian Ocean. Geodynamics of Pakistan, 13, 5-24.

[17] Yeats, R.S. and Lawrence, R.D. (1984) Tectonics of Himalayan Thrust Belt in Northern Pakistan. In: Haq, B.U. and Milliman, J., Eds., Marine Geology and Oceanography of the Arabian Sea and Coastal Pakistan, Van Nostrant Reinhold Co., New York, 177-198.

[18] Burg, J.-P., Célérier, B., Chaudhry, M.N., Ghazanfar, M., Gnehm, F. and Schnellmann, M. (2005) Fault Analysis and Paleostress Evolution in Large Strain Regions: Methodological and Geological Discussion of the Southeastern Himalayan Fold-and-Thrust Belt in Pakistan. Journal of Asian Earth Sciences, 24, 445-467. https://doi.org/10.1016/j.jseaes.2003.12.008

[19] Aitchison, J.C., Ali, J.R. and Davis, A.M. (2007) When and Where Did India and Asia Collide? Journal of Geophysical Research: Solid Earth, 112, 1-19. https://doi.org/10.1029/2006JB004706

[20] Khan, S.D., Walker, D.J., Hall, S.A., Burke, K.C., Shah, M.T. and Stockli, L. (2009) Did the Kohistan-Ladakh Island Arc Collide First with India? Geological Society of America Bulletin, 121, 366-384. https://doi.org/10.1130/B26348.1

[21] Chaudhry, M.N., Ghazanfar, M., Ramsay, J.G., Spencer, D.A. and Qayyumm, M. (1994) Northwest Himalaya-A Tectonic Subdivision. Geology in South Asia-1: Proceeding of First South Asia Geological Congress, Islamabad, 23-27 February 1992, 175-184.

[22] McDoughall, J.W., Hussain, A. and Yeats, R.S. (1993) The Main Boundary Thrust and Propogation of the Deformation into the Foreland Fore and Thrust Belt in the Northern Pakistan near the Indus River. Tectonics of Western Himalaya. Geol. Soc. America, Special Publication 74, 581-588. https://doi.org/10.1144/GSL.SP.1993.074.01.38

[23] Qureshi, K.A. and Ahmad, M. (2001) Geological Map of Kalachitta Range, Northern Punjab, Pakistan. Geol. Surv. Pakistan, Quetta.

[24] Fatmi, A. (1969) Dimorphism in Some Jurassic and Lower Cretaceous Ammonites from West Pakistan. Geonews, 1, 6-13.

[25] Fatmi, A.N. (1977) Neocomian Ammonites from Northern Areas of Pakistan. British Museum (Natural History).

[26] Jaswal, T.M., Lillie, R.J. and Lawrence, R.D. (1997) Structural Evolution of Northern Potwar Deformed Zone, Pakistan. AAPG, 81, 308-352.

[27] Flügel, E. (2004) Microfacies Data: Fabrics Microfacies of Carbonate Rocks. Sprin- 
ger, Berlin.

[28] Dickson, J. (1965) A Modified Staining Technique for Carbonates in Thin Section. Nature, 205, 4971-4979. https://doi.org/10.1038/205587a0

[29] Dunham, R.J. (1962) Classification of Carbonate Rocks According to Depositional Textures.

[30] Dodd, J.R. and Stanton, R.J. (1990) Paleoecology: Concepts and Applications. John Wiley \& Sons, Hoboken.

[31] Reading, H.G. (2009) Sedimentary Environments: Processes, Facies and Stratigraphy. John Wiley \& Sons, Hoboken.

[32] Ahsan, N. (2008) Facies Modeling, Depositional and Diagenetic Environments of Kawagarh Formation, Hazara Basin, Pakistan. Unpublished PhD Thesis, Punjab University, Lahore.

[33] Postuma, J.A. (1971) Manual of Planktonic Foraminifera. Elsevier Publishing Company, New York.

[34] McDaniel, L., Houchin, L., Williamson, S. and Paul, J. (2002) Plankton Blooms: Lysogeny in Marine Synechococcus. Nature, 415, 496-496.

https://doi.org/10.1038/415496a

[35] Berger, W.H. (1970) Planktonic Foraminifera: Differential Production and Expatriation off Baja California. Limnology and Oceanography, 15, 183-204. https://doi.org/10.4319/lo.1970.15.2.0183

[36] Tucker, M.E. and Wright, V.P. (1990) Carbonate Mineralogy and Chemistry. Carbonate Sedimentology, 284-313. https://doi.org/10.1002/9781444314175.ch6

[37] Logan, B.W., Bass, M.N. and McBirney, A.R. (1969) Carbonate Sediments and Reefs, Yucatan Shelf, Mexico. American Association of Petroleum Geologists, Mmoirs, 11.

[38] Hart, M.B., Callapez, P.M., Fisher, J.K., Hannant, K., Monteiro, J.F., Price, G.D. and Watkinson, M.P. (2005) Micropalaeontology and Stratigraphy of the Cenomanian/Turonian Boundary in the Lusitanian Basin, Portugal. Journal of Iberian Geology, 31, 311-326.

[39] Frank, R., Buchbinder, B. and Benjamini, C. (2010) The Mid-Cretaceous Carbonate System of Northern Israel: Facies Evolution, Tectono-Sedimentary Configuration and Global Control on the Central Levant Margin of the Arabian Plate. Geological Society, London, Special Publications, 341, 133-169.

[40] Hart, M.B. (2012) Geodiversity, Palaeodiversity or Biodiversity: Where Is the Place of Palaeobiology and an Understanding of Taphonomy? Proceedings of the Geologists Association, 123, 551-555. https://doi.org/10.1016/j.pgeola.2012.05.006

[41] Boggs, S. (2009) Petrology of Sedimentary Rocks. Cambridge University Press, Cambridge. https://doi.org/10.1017/CBO9780511626487

[42] Stanley, S.M. (1977) Trends, Rates, and Patterns of Evolution in the Bivalvia. Developments in Palaeontology and Stratigraphy, 5, 209-250. https://doi.org/10.1016/S0920-5446(08)70327-3

[43] Qureshi, M.K.A., Masood, K.R., Ghazi, S. and Butt, A.A. (2006) Lithofacies Analysis of the Lower Cretaceous Lumshiwal Formation, Kala Chitta Range, Northern Pakistan. Geological Bulletin of Punjab University, 41, 1-19.

[44] Salazar Soto, C.A. (2012) The Jurassic-Cretaceous Boundary (Tithonian Hauterivian) in the Andean Basin of Central Chile: Ammonites, Bio- and Sequence Stratigraphy and Palaeobiogeography. Unpublished $\mathrm{PhD}$ Thesis, Der Rupecht-Karls-Universität Heidelberg, Chile. 
[45] Ahr, W.M. (1989) Sedimentary and Tectonic Controls on the Development of an Early Mississippian Carbonate Ramp, Sacramento Mountains Area, New Mexico.

[46] Burchette, T. and Wright, V. (1992) Carbonate Ramp Depositional Systems. Sedimentary Geology, 79, 3-57. https://doi.org/10.1016/0037-0738(92)90003-A

[47] Rey, J. (1997) A Liassic Isolated Platform Controlled by Tectonics: South Iberian Margin, Southeast Spain. Geological Magazine, 134, 235-247. https://doi.org/10.1017/S0016756897006651

[48] Pomar, L. (2001) Types of Carbonate Platforms: A Genetic Approach. Basin Research, 13, 313-334.

[49] Ahsan, N., Rehman, S.U. and Shah, M.M. (2015) Kawagarh Formation (Turonian to Lower Maastrichtian) - A Homoclinal Ramp Deposit in Hazara Basin on Northern Margin of the Indian Plate. 15th Bathurst Meeting, University of Edenburgh, England, 13-16 July 2015.

[50] Wilson, J.L. (2012) Carbonate Facies in Geologic History. Springer-Verlag, Berlin.

[51] Wright, V. (1986) Facies Sequences on a Carbonate Ramp: The Carboniferous Limestone of South Wales. Sedimentology, 33, 221-241. https://doi.org/10.1111/j.1365-3091.1986.tb00533.x

[52] Haq, B.U., Hardenbol, J. and Vail, P.R. (1988) Mesozoic and Cenozoic Chronostratigraphy and Cycles of Sea Level Change. In: Wilgus, C.K., Hastings, B.S., Kendall, C.G.St.C., et al., Eds., Sea-Level Changes: An Integrated Approach, SEPM Special Publication 42, SEPM, Tulsa, 7-108. 